\title{
Use of Ion-Selective Electrodes in Tobacco and Tobacco Smoke Analyses: A Review*
}

\author{
by G. P. Morie \\ Research Laboratories, Tennessee Eastman Company, \\ Division of Eastman Kodak Company, Kingsport, Tennessee, U.S.A.
}

\section{INTRODUCTION}

The current interest in ion-selective electrodes can probably be traced to an announcement by Frant and Ross $(1,2)$ in 1966-1967 of the fluoride and calcium electrodes. However, these developments actually began at the turn of the century with Cremer's discovery of the hydrogen-responsive glass electrode. No startling new principle led to the introduction of non-glass ion-selective electrodes and to the publication of thousands of papers on these electrodes in the late 1960's and early 1970's. Rather, this new field of potentiometry resulted from the steady increase in knowledge in related fields. Haber and Klemensiewicz (3) made detailed studies of the response of the glass electrode to hydrogen ions. The concept that an ion exchange process occurs across the glass membrane was introduced by Nikolski and Tolmacheva $(4,5)$. However, not until the classic tracer experiments by Schawbe and Dabms (6) and the fundamental studies by Eisenman $(7,8)$ did a good understanding of ion-selective electrodes occur.

It is not the purpose of this paper to review the entire field of ion-selective electrodes. Several excellent reviews, monographs, books, and manufacturer's literature are available for this purpose (9-13). This paper is intended as a brief summary of the state-of-the-art and a guide to applications and possible applications of ionselective electrodes to tobacco and tobacco smoke analyses.

\section{MATERIALS AND METHODS}

\section{Theory and Operating Principles}

The electromotive force (EMF) generated by an ionselective electrode is related to ionic activities in the sample solution by an extended form of the Nernst equation known as the Nicolsky equation:

$$
E=E_{0}+\frac{R T}{n F} \ln \left[a_{i}+\Sigma K_{i j}\left(a_{j}\right)^{n_{j} / n_{j}}\right]
$$

\footnotetext{
"Received for publication: 26th September, 1976.
}

where:

$\mathrm{E}=$ cell potential,

$\mathrm{E}_{0}=$ cell potential at unit activity,

$\frac{\mathrm{RT}}{\mathrm{nF}}=$ Nernst factor,

$a_{i}=$ activity of primary ion in solution,

$a_{j}=$ activity of secondary ion in solution,

$\mathrm{K}_{\mathrm{ij}}=$ selectivity factor characteristic of a given electrode membrane.

Values for the selectivity, $K_{i j}$, range from insignificantly small values to numbers greater than unity. A list of selectivity constants are given in several publications (14), and these should be considered before attempting to use ion-selective electrodes for a given analysis.

To measure the potential, $\mathrm{E}$, of a solution, the ionselective electrode is connected to a high impedance voltmeter, and the circuit is completed via a second reference electrode. The voltmeter or amplifier should be very stable and have an input impedance $>10^{18}$ ohms. The meter should be capable of measuring the response to $\pm 0.1 \mathrm{mV}$. The electrodes are usually immersed in the solution to be measured; and one of the several types of measurements, which are described in a later section of this paper, is employed.

\section{Types of Electrodes}

The classification of ion-selective electrodes based on the type of fabrication (solid state, heterogeneous, and liquid ion-exchange types) is no longer valid, because some active materials can be used in all three types. Electrodes are now classified in four groups according to the active material present in them:

1. Glass electrodes;

2. Electrodes containing an insoluble inorganic salt, either in the form of a single crystal or dispersed in a matrix such as silicone rubber;

3. Electrodes containing long-chain ion-exchanger materials such as alkyl phosphate salts or complexing agents; 
Table 1. Princlpal lon-selective electrodes.

\begin{tabular}{ll|l|l}
\hline & Cation & Anion & Gaseous \\
\hline $\mathrm{H}^{+}$ & $\mathrm{Ca}^{2+}$ & $\mathrm{F}^{-} \mathrm{SO}_{4}^{2-}$ & $\mathrm{NH}_{3}$ \\
$\mathrm{Li}^{+}$ & $\mathrm{Ca}^{2+} / \mathrm{Mg}^{2+}$ & $\mathrm{Cl}^{-}$ & $\mathrm{SO}_{2}$ \\
$\mathrm{Na}^{+}$ & $\mathrm{Ba}^{2+}$ & $\mathrm{Br}^{-}$ & $\mathrm{NO} / \mathrm{NO}_{2}$ \\
$\mathrm{~K}^{+}$ & $\mathrm{Cu}^{2+}$ & $1^{-}$ & $\mathrm{HCN}$ \\
$\mathrm{NH}_{4}{ }^{+}$ & $\mathrm{Fe}^{3+}$ & $\mathrm{S}^{2-}$ & $\mathrm{CO}_{2}$ \\
$\mathrm{Ag}^{+}$ & $\mathrm{Zn}^{2+}$ & $\mathrm{ClO}_{4}^{-}$ & $\mathrm{H} \mathrm{S}^{-}$ \\
& $\mathrm{Mn}^{2+}$ & $\mathrm{NO}_{3}^{-}$ & $\mathrm{HF}$ \\
& $\mathrm{Cd}^{2+}$ & $\mathrm{BF}_{4}^{-}$ & $\mathrm{HOAc}$ \\
& $\mathrm{Ni}^{2+}$ & $\mathrm{SCN}^{-}$ & $\mathrm{Cl}$ \\
& $\mathrm{Pb}^{2+}$ & $\mathrm{CN}^{-}$ & \\
\hline
\end{tabular}

4. Gas-permeable membrane electrodes, the selectivity of which depends upon the ability of a given gas to diffuse through a polymer membrane.

The principal ion-selective electrodes that are commercially available, or that are relatively easy to construct, are given in Table 1. Many other ions can be measured indirectly by means of titrations in which the titrant is monitored with an ion-selective electrode. In addition, several species for which no electrode exists, can be converted into an ion that can be measured with an existing ion-selective electrode.

\section{Types of Measurements}

Ion-selective electrodes may be used to measure the concentration of an ion by one of several techniques:

Direct Calibration: A series of standard solutions of known concentration are prepared, and the potential of these solutions is measured. For routine work, it is convenient to use two solutions and a meter which can be adjusted to give the concentration directly. Alternatively, the potential of several known solutions can be recorded, and the electrode potential is plotted against the concentration on semilog graph paper. In either procedure, the electrode responds to ionic activity, not concentration; and it is recommended that some salt solution be added to both the unknown solution and the standards to adjust the ionic strength to approximately the same value. Sometimes a buffer is also needed to convert the species of interest to an ion that can be measured. For example, all of the $\mathrm{H}_{2} \mathrm{~S}$ must be converted to $\mathrm{S}^{2}-$ at high $\mathrm{pH}$ before the sulfide electrode can be used to measure sulfide.

Known Addition Metbod: The known addition (or known subtraction) technique is used to eliminate any matrix differences between the unknown sample and standard solutions. A second advantage is that the entire calibration step can be eliminated. The initial potential of a solution is measured. Then a small volume of standard solution is added to give a potential approximately double the original reading. From the volume and concentration of the standard used and the change in potential, the unknown concentration can be measured. Known addition tables are available from the manufacturers of ion selective electrodes (13), and the sample concentration can be read from the table when both the potential change and standard concentration are known. This technique is particularly useful when only an occasional sample is measured.

Titrations: Increased accuracy and precision may be obtained when ion-selective electrodes are used in titrations. A second advantage is that species not directly sensed by the electrode may be determined. For example, sulfate can be titrated with a lead solution, and the potential can be monitored with a lead electrode. Species that complex with metal ions, such as copper, may be titrated with a copper solution. Although only a simple burette is needed in addition to the electrodes and meter, the technique may be automated with an automatic titrator.

\section{RESULTS AND DISCUSSION}

\section{Application of Ion-Selective Electrodes to Tobacco Smoke}

Cyanide Electrodes: The determination of cyanide in tobacco smoke with a cyanide electrode was reported by Vickroy and Gaunt (15) and Reif (16). Both methods are based on the collection of hydrogen cyanide on Ascarite traps. Lead nitrate is added in both procedures to precipitate any sulfide that may be present. Two different measuring techniques, direct measurement and standard addition, were evaluated in these investigations. The standard addition procedure was recommended because it gave results that were in good agreement with colorimetric methods and because the precision obtained by this method was superior to that obtained by direct reading. The authors of both papers state that the results obtained by the standard addition technique are comparable to those obtained by the pyridine/benzidine colorimetric method (17). For example, the colorimetric method indicated that the smoke of a typical domestic blend cigarette contained $270 \mu \mathrm{g} \mathrm{HCN}$; the electrode gave $255 \mu \mathrm{g}$.

Sulfide Electrode: Even though the level of hydrogen sulfide in cigarette smoke is very low (about $40 \mu \mathrm{g} /$ cigarette), a sulfide ion electrode was successfully used for this determination. The silver sulfide, solid-state electrode responds to extremely small quantities of sulfide ion (18). However, an antioxidant buffer must be used to prevent oxidation of sulfide ion in dilute solutions and to insure stable electrode readings. The gas phase of smoke was collected in a scrubber that was $1 M$ in sodium hydroxide and $0.01 \mathrm{M}$ in ascorbate ion. After the sample was trapped, the solution was diluted to a known volume; the potential was measured; and the sulfide ion concentration was calculated. The coefficient of variation of the method was $4.3 \%$ at a concentration level of $40 \mu \mathrm{g} / \mathrm{cigarette}$. The method was used to evaluate the removal of $\mathrm{H}_{2} \mathrm{~S}$ from cigarette smoke by various filters.

Nitrogen Oxides: The first application of ion-selective electrodes to tobacco smoke of which the author is aware was the use of the nitrate ion electrode for the determination of nitric oxide in tobacco smoke (19). The 
nitrate ion electrode responds to a small extent to nitrite ion. Morie, Ledford, and Glover took advantage of this response to determine nitrate ion and nitrite ion in mixtures (20). However, to rapidly determine the total nitrogen oxides in tobacco smoke, an alternate method is recommended. The nitric oxide, which virtually accounts for all of the nitrogen oxides in tobacco smoke, is oxidized with hydrogen peroxide to $\mathrm{N}_{2} \mathrm{O}_{5}$, which rapidly hydrolyzes to $\mathrm{HNO}_{3}$ (21). The resulting nitrate ion is measured with a nitrate ion electrode, and the corresponding $\mathrm{NO}$ in the original smoke sample is calculated. The standard deviation of the determination is $3.1 \mu \mathrm{g}$ for a concentration of $270 \mu \mathrm{g} /$ cigarette. The method is more rapid than the Griess colorimetric procedure (22), and it requires less expensive equipment than does the chemiluminescence method (23).

A gas sensing electrode that responds directly to $\mathrm{NO}$ and $\mathrm{NO}_{2}$ is now available (24) and has been applied to air quality analyses. This electrode should be useful for the determination of nitrogen oxides in tobacco smoke; but to the author's knowledge, this has not been done.

Ammonia: Soon after the ammonia electrode with a gaspermeable membrane was introduced commercially, it was applied to the determination of ammonia in cigarette smoke and tobacco $(25,26)$. Whole cigarette smoke was trapped in an aqueous scrubber solution. The scrubber solution was made basic just before it was steam distilled; the ammonia that was released was caught in a $0.1 \mathrm{M}$ $\mathrm{HCl}$ solution. Just prior to measurement with the electrode, the solution was made basic with a small volume of $10 \mathrm{M}$ sodium hydroxide.

In general, the results of this method agreed well with other methods. However, on some samples somewhat higher quantities of ammonia were indicated by the electrode method than were found by other methods. It was suspected that some amides were hydrolyzed during the steam distillation, and this contributed to the high value.

Approximately a year after the ammonia electrode was introduced, Orion Research, Inc. described the use of the ammonia electrode to detect ammonia in the head space above a liquid. The electrode was suspended above a basic solution that contained the sample. This technique was used by Sloan and Morie to measure the amount of total ammonia and the amounts of free gaseous (unprotonated) ammonia in mainstream cigarette smoke. Whole smoke was trapped in an aqueous acidic scrubber solution. After smoking, the scrubber solution was placed in a flask. The ammonia electrode was suspended about $3 \mathrm{~mm}$ above the liquid. The solution was made basic with a small volume of $10 \mathrm{M}$ sodium hydroxide. Ammonia diffused out of the solution and gave rise to a potential reading that was compared to a potential for a known concentration of ammonia.

Because the ammonia electrode responds to free gaseous ammonia, the authors applied the electrode to the detection of free gaseous ammonia in mainstream cigarette smoke (27). It was found that extremely small quantities of the total ammonia in cigarette smoke are present as free gaseous ammonia. These results are consistent with the $\mathrm{pH}$ of cigarette smoke and the ionization constant of ammonia. At a $\mathrm{pH}$ of 5.5 to 6.0, virtually all of the ammonia exists as a salt, and is present as part of the particulate matter.

Sulfur Dioxide: The level of sulfur dioxide in smoke is quite low (28). Attempts to measure the $\mathrm{SO}_{2}$ in cigarette smoke with a sulfur dioxide electrode, of which the author is aware, were unsuccessful (29).

\section{Applications and Possible Applications to Tobacco Ana- lyses}

Nitrate: The nitrate ion electrode was applied to the determination of nitrate in tobacco by Jacin (30). Ions that might have interfered with the determination were removed with an ion-exchange treatment. An aqueous slurry of the tobacco was filtered, and nitrate ion concentration was measured directly on the filtrate with the electrode. The precision of the method is equal to that of the colorimetric method based on 2,4-xylenol. Moreover, the electrode method is more rapid than most of the previous methods used for the determination of nitrate in tobacco.

Ammonia: The ammonia gas electrode was used to measure the total ammonia concentration in tobacco (26). Ground tobacco was added to an alkaline buffer, and the mixture was steam distilled. The distilled ammonia was trapped in a scrubber and measured with the ammonia electrode. The ammonia present as ammonium salts and ammonia resulting from the decomposition of certain organic compounds is included in the measurement.

Cations: Several metal ions that are present in tobacco can be measured with ion-selective electrodes. Three of the most common of these are $\mathrm{Ca}^{2+}, \mathrm{Mg}^{2+}$, and $\mathrm{K}^{+}$. The author is unaware of any determinations of these ions in tobacco by ion-selective electrodes at present. This is probably because it is convenient to determine these three ions as well as other metallic elements, by well-established techniques such as flame photometry and atomic absorption spectroscopy.

Anions: Other ions that are routinely measured in tobacco and which can be determined by electrodes are halogens, particularly chloride. However, none of the halogens are normally determined with ion-selective electrodes because other convenient methods, such as potentiometric titrations with a silver/silver halide electrode, are used. In general, ion-selective electrodes have found the most application for the determinations that are difficult by other means.

Finally, two species that are measured in tobacco are $\mathrm{SO}_{4}^{2-}$ and $\mathrm{PO}_{4}{ }^{2-}$. From time to time, electrodes which are sensitive to these ions have been reported; but they were not entirely satisfactory. However, either of these ions can be titrated with a metal such as $\mathrm{Ca}^{2+}$ or $\mathrm{Pb}^{2+}$ and the titration is conveniently followed with an electrode that responds to the metal ion. This technique was described in detail in a paper by Hicks (31). 


\section{SUMMARY}

Ion-selective electrodes have been used for the rapid determination of many components in tobacco and tobacco smoke. The determinations of the following tobacco smoke components with ion-selective electrodes are reviewed: hydrogen sulfide with a sulfide electrode, hydrogen cyanide with a cyanide electrode, nitrogen oxides with a nitrate electrode, and ammonia with an ammonia electrode. The determination of nitrate and ammonia in tobacco is also described. Some possible applications of ion-selective electrodes are discussed, based on the electrode sensitivity and selectivity and the level of certain components in tobacco or tobacco smoke.

\section{ZUSAMMENFASSUNG}

Ionenselektive Elektroden wurden für die schnelle Bestimmung vieler Inhaltsstoffe des Tabaks und des Tabakrauches benutzt. Die Bestimmung folgender Bestandteile des Tabakraudhes unter Einsatz ionenselektiver Elektroden wird kommentiert: Schwefelwasserstoff mittels einer Sulfidelektrode, Cyanwasserstoff mittels einer Cyanidelektrode, Stickoxide mittels einer Nitratelektrode und Ammoniak mittels einer Ammoniakelektrode. Es wird ferner die Bestimmung von Nitrat und Ammoniak im Tabak beschrieben. Auf der Grundlage der Empfindlichkeit und Selektivität der Elektroden sowie der Menge bestimmter, in Tabak und Tabakrauch enthaltener Verbindungen werden einige Anwendungsmöglichkeiten ionenselektiver Elektroden diskutiert.

\section{RESUME}

Des électrodes iono-sélectives ont été utilisées pour la détermination rapide de plusieurs composés dans le tabac et la fumé de tabac. L'on passe en revue la détermination à l'aide de méthodes iono-sélectives des composés de tabac suivants: le sulfure d'hydrogène à l'aide d'une électrode au sulfure, le cyanure d'hydrogène à l'aide d'une électrode au cyanure, les oxydes d'azote à l'aide d'une electrode au nitrate, et l'ammoniaque à l'aide d'une électrode à l'ammoniaque. La détermination de la teneur du tabac en nitrate et en ammoniaque est également décrite. L'on discute certaines applications possibles pour les électrodes iono-sélectives, en se basant sur la sensibilité et la sélectivité de ces électrodes, et la teneur de certains composants dans le tabac et la fumée de tabac.

\section{REFERENCES}

1. Frant, M. S., and J. W. Ross: Science 154 (1966) 1553.

2. Ross, J. W.: Science 156 (1967) 1378.

3. Haber, F., and Z. Klemensiewicz: Z. Phys. Chem. 67 (1909) 385.
4. Nikolski, B. P., and T. A. Tolmacheva: Zh. Fiz. Khim. 10 (1937) 495.

5. Nikolski, B. P., and T. A. Tolmacheva: Zh. Fiz. Khim. 10 (1937) 513.

6. Schawbe, K., and H. Dahms: Monatsber. Dtsch. Akad. Wiss. Berlin 1 (1959) 279.

7. Eisenman, G.: Biophys. J. 2 (1962) 259.

8. Eisenman, G., D. O. Rudin, and J. U. Cosby: Science 126 (1957) 831.

9. Moody, G. J., and J. D. R. Thomas: Selective ionsensitive electrodes; Merrow Publishing Co. Ltd., Watford, Herts, England, 1971.

10. Covington, A. K.: Crit. Rev. Anal. Chem. 3 (1974) 355.

11. Koryta, J.: Anál. Chim. Acta 61 (1972) 329.

12. Meredith, W. D.: Chem. Ind. 1974, 5, 764.

13. Orion Research, Inc.: Analytical methods guide; Orion Researd, Inc., 11 Bladkstone St., Cambridge, Mass., U.S.A., May 1975.

14. Orion Research, Inc.: Individual data sheets on ionselective electrodes; Orion Research, Inc., 11 Bladstone St., Cambridge, Mass., U.S.A.

15. Vidkroy, D. G., and G. L. Gaunt, Jr.: Tob. Sci. XVI (1972) 22.

16. Reif, H.: Fachliche Mitt. Oesterr. Tabakregie 1972, $13,220$.

17. Artho, A., and R. Koch: Beitr. Tabakforsch. 5 (1969) 58.

18. Morie, G. P.: Tob. Sci, XV (1971) 107.

19. Morie, G. P., C. J. Ledford, and C. A. Glover: 22nd 'Tobacco Chemists' Researdh Conference, Richmond, Va., Oct. 1968.

20. Morie, G. P., C. J. Ledford, and C. A. Glover: Anal. Chim. Acta 60 (1972) 397.

21. Sloan, C. H., and G. P. Morie: Tob. Sci. XVIII (1974) 102.

22. Saltzman, B. E.: Anal. Chem. 26 (1954) 1949.

23. Rothwell, K., and C. A. Grant: Standard methods for the analysis of tobacco smoke; Tobacco Research Council, London, England, 1974.

24. Nitrogen oxide electrode, Model 95-46; Orion Research, Inc., 11 Bladkstone St., Cambridge, Mass.

25. Sloan, C. H., and G. P. Morie: 27th Tobacco Chemists' Research Conference, Winston-Salem, N.C., Oct. 1973.

26. Sloan, C. H., and G. P. Morie: Anal. Chim. Acta 69 (1974) 243.

27. Sloan, C. H., and G. P. Morie: 29th Tobacco Chemists' Research Conference, College Park, Md., Oct. 1975.

28. Elmenhorst, H., and C. Schultz: Beitr. Tabakforsch. 4 (1968) 90.

29. Sloan, C. H.: Private communication.

30. Jacin, H.: Tobacco Sci. XIV (1970) 28.

31. Hidss, J. E., J. E. Fleenor, and H. R. Smith: Anal. Chim. Acta 68 (1974) 480.

The author's address:

Researdh Laboratories, Tennessee Eastman Company, Kingsport, Tennessee, 37662, U.S.A. 